\title{
South African Mobile Telecommunication Expansion into Emerging Markets: What to look out for
}

\author{
DR JOSEPH SIGAUKE, DR EMMANUEL MUTAMBARA \\ University of KwaZulu-Natal \\ Email: hiejose@yahoo.com (DR JOSEPH SIGAUKE), mutambarae@ukzn.ac.za (DR \\ EMMANUEL MUTAMBARA)
}

\begin{abstract}
Mobile telecommunication (telecom) firms often face strategic, political, technological, infrastructural, and legal challenges during international expansion. Although some telecom companies have been successful in their expansion beyond borders, others closed down and returned to their countries of origin and South African (SAn) telecom firms are no exception. The aim of this paper is to outline SAn telecom firm's market and discuss strategic factors which enhance successful expansion of mobile telecom companies into emerging markets. This research was undertaken using SAn listed mobile telecom firms. A response rate of $79 \%$ and $98 \%$ was obtained from the questionnaires and interviews, respectively. The study demonstrated that language and culture, resources, strategy, efficiency, and competitiveness impacts telecom firms' growth within African markets; hence their compatibility during expansion is important. Additional factors considered were infrastructural development, human resources and government's role. These factors were observed to have a bearing on the telecom firm's competitiveness, ease of doing business and overall business success in the
\end{abstract}


emerging markets. This study recommends that telecom firms minimise these factors' negative impact whilst taking advantage of their positive influence.

KeyWords: Competitiveness, Efficiency, Expansion, Government, Resources, Strategy, Telecommunication.

[Disclaimer: These are the opinions of the author and not of the telecom firms]

\section{INTRODUCTION}

There are reasons why becoming global has become a strategic imperative for virtually any small, medium or large corporation particularly in Africa where there is potential for growth, like in the mobile telecom industry. Primarily, the need for profitability, growth, efficiencies, knowledge, globalisation of customers and competitors has been on the forefront pushing companies to expand beyond their national boundaries (Hill, 2012:6; Gupta \& Govindarajan, 2000:45). The growth in the mobile telecom sector was further propelled by its impact to the economy through the multiplier effect (Stanlake, 2008:53). Companies exist and thrive to grow and ensure a good return to their shareholders. This prompted telecom companies to grow beyond their borders. Interestingly, communication and technology was fundamental for firms' globalisation and the creation of a borderless world (Ghemawat, 2008:1). Central to the provision of this service are mobile telecom firms which offer internet services.

\section{LITERATURE REVIEW}

In Africa, during the late 1990s into early 2000s, adventurous telecom investment capitalists bought Global System for Mobile (GSM) licences at very low prices from African governments on the eve of GSM communication technology in Africa (Maketa, 2009:18). In early 2000, these "GSM ventures displayed high profitability and this resulted in an investment rush in African telecom infrastructure, translating into an increase in mobile penetration" (Reed, 2009). In support of the business growth potential, the Central Bank of South Africa (SA) increased the borrowing threshold for companies expanding into Africa and outside of Africa to R2 billion and R1 billion, respectively. SAn telecom firms benefited 
from the facility as well, as telecom firms sought to grow beyond borders post-apartheid (Maketa, 2009:18).

Mobile penetration rate in Africa stood at 38\% in 2014 and grew to $41 \%$ by 2015 and is projected to grow to $54 \%$ by 2020 (Global System for Mobile Association (GSMA), 2014:2; GSMA, 2015:2; GSMA, 2016:9) against a saturation of networks in developed countries. Hence, telecom firms scrambled to get any operating licence or strategic consolidation in Africa. SAn telecom companies also joined in the scramble for GSM licences as they aggressively expanded. The massive investment "interest in Africa is explained by Africa's low GSM penetration rate compared to the size and magnitude of its market" (Maketa, 2009:18). The opportunities in emerging markets propped developed market telecom operators to seek opportunities in emerging markets; hence, intensifying the degree of competition for mobile operators. Against this background, the operating landscape in emerging markets is different and unique, requiring different skills set, strategies, resources, different business approaches and organisational set-ups. This research looked at the expansion of mobile telecom firms within an emerging market context and explored factors which SAn telecom firms should consider as they grow beyond borders.

According to Ernest \& Young (2009:5), “telecom has a direct influence on the economy's performance. It is estimated that a $10 \%$ increase in telephone penetration results in $1.2 \%$ increase in Gross Domestic Product (GDP) in emerging market countries and $0.6 \%$ in developed countries". The high level of potential in Africa pushed telecom expansion into Africa and SAn telecom companies were not left out either. The expansion process reported successes and failures. Telkom failed in Nigeria, due to liquidity and operational challenges. In Iran, MTN is facing challenges to repatriate profits for further expansion into other markets. In Nigeria, MTN was fined US\$3.9 billion for not complying with a government regulation to have all issued SIM cards registered (Ibukunu, 2017:1). Vodacom is also under compulsion in Tanzania to issue equity to the locals, but this was not in the original agreement when they got their operating license (Ng'wanakilala, 2017:1).

This mixed turn of events made it imperative to explore mobile telecom firms in emerging markets and factors that impact their strategic expansion. It has to be noted that culture, language, resources, strategies and the way to operate in Africa were taken into account as telecom firms grow beyond SAn borders because they influence operations in emerging markets. 
There have been massive growth, decline, investment, divestment, integration and joint ventures of mobile telecom firms around the world. Much of the activity has been coming from Europe and Asia. However, whilst the hive of activity has reached saturation in those markets, Africa still has growth opportunities (GSMA, 2016:5). The focus shifted to Africa, and SAn mobile telecom firms are expanding in African emerging markets. The main challenge is: how do African mobile telecom firms compete against the advanced market firms that have been exposed and have amassed vast expansion experience in many international markets? This is why this research was in place, to guide emerging market telecom firms as they expand beyond borders, and give pointers on factors to consider as they grow so as to enhance chances of success.

\section{RESEARCH METHODOLOGY}

The research was undertaken using mixed methods approach. Primary data was obtained using questionnaires and interviews, whilst secondary data was obtained from financial reports, company websites and newspaper articles. The SAn telecom firms were purposively sampled by selecting telecom firms listed on the JSE market. A response rate of $79 \%$ and $98 \%$ was obtained from questionnaires and interviews, respectively.

\section{RESULTS AND DISCUSSION}

The results explored the market's analysis, diamond model, five forces model and other institutional factors that impact telecom firms' expansion.

\subsection{Market analysis: Expansion beyond South Africa}

The research found that there is a high priority for expansion by SAn telecom businesses into emerging markets. GSMA (2015:17) showed that Africa's growth overtook Asia which was on $9 \%$ and Africa stood at $13 \%$ in terms of Compounded Annual Growth Rate (CAGR) in the world. This supports the enthusiasm shown by SAn telecom firms to expand. The strategic expansion by telecom firms in Africa was further enhanced by GDP growth potential in Africa which grew at a constant CAGR of 5.5\% in 2017, second to China. Further, the African market GDP growth forecast is looking positive.

\subsubsection{Potential markets}


The study showed that there is a high growth potential in the African telecom market. Investment potential into Africa was high, whilst low in the Middle-East regions. The research showed little investment and expansion interest in Europe and the United States. This is because these markets are saturated, and there is high competition with little penetration due to the maturity level in the telecom industry's life cycle (Grant, 2016:330). In addition, a Deloitte (2014:4) study showed that North African countries and the Middle-East regions are about to reach maturity. In Sub-Sahara region, there is still good opportunity for growth in the telecom industry.

\subsubsection{Closing foreign operations}

The study observed that there are various business challenges in emerging markets, but SAn telecom firms are resolute and tolerant because the market has good ROI potential. The challenges telecom firms face in emerging markets include regulatory and policy changes, corruption allegations, changes in legislations, fines for improper conduct and shareholder infighting.

If the challenges are something to go by, then companies such as Vodacom and MTN could have pulled out. For instance, MTN's fine was a world record in the telecom industry (Ambekar, 2016:8; MTN, 2016:56). The Nigerian fine culminated into a drop in MTN's subscriber base. This was further worsened by a regulatory ban on MTN from increasing tariffs. MTN's promotional activities were also halted; hence, MTN's revenue and profitability were negatively affected (Ambekar, 2016:8). However, the fact that MTN is still in Nigeria, cements this research's findings that SAn telecom firms are unlikely to close operations in emerging markets. Vodacom's financials also illustrate continued positive contribution by foreign operations in the group (Vodacom, 2016:55). In addition, Vodacom almost pulled out of DRC in 2010 because of shareholder problems with its joint venture partner, but Vodacom remained in DRC because of the market's good ROI and future potential growth (Vodacom, 2011:23).

\subsection{Strategic expansion factors to consider}

\subsubsection{Diamond model: Telecom firms' competitiveness}

This research observed that SAn telecom firms are competitive in their various markets of operation. Porter's (1990:2) diamond model broke down factors which telecom firms can look at in enhancing competitiveness as they expand (Hill, 2012:181). The four factors in the diamond model and the five forces of industrial analysis are explored in relation to SAn 
mobile telecom firms (Thompson, Strickland \& Gamble, 2016:57). According to Hill's (2012:181) analysis, the diamond model is a basic unit of analysis for understanding competition in the telecom industry. Thus, it is an arena where competitiveness and competitive advantage is won or lost, and it is the firm's responsibility to fight and define its position in the market or country of operation. The factors are discussed below.

\subsubsection{Factor endowments/conditions}

Factor conditions are the basic inputs which go into the firm's operations process to enhance competitiveness. These include physical, human, capital and infrastructural resources, among others. Human resource (HR) is an important aspect to consider during expansion, as human capital is responsible for conceptualising the expansion strategy, execution and control thereof (Hchaichi, 2014:205; Cascio, 2013:4). In addition, the study found that an assessment of the country's labour market and laws that govern the labour market is important as a telecom firm expands, as HR has a fundamental impact on a firm's competitiveness. To ensure successful expansion of telecom firms, achievement of business objectives, correct and precise implementation of the corporate and business strategy, it is essential to ensure that the business has and can attract and retain skilled human capital which works as a resource to attain good results during expansion.

The study observed that SAn telecom firms are not competitive in retaining human resources' skills in emerging markets. The research observed that telecom firms lack strong competitive HR strategies on the international front to support foreign expansion. This was also further emphasised by Telkom. Telkom retrenched employees during its turnaround strategy and this threatens DNA, skills and capabilities transfer as firms expand. According to Cascio (2013:289), skills transfer is one of the fundamental methods which ensure the preservation of a firm's DNA. Skills transfer assists in sharpening telecom firms' operations during expansion. The research observed that that skills retention and staff development on the local labour markets is low. This is attributed to by telecom firms' corporate strategies that are not human resources centric in line with growth, financial strength and expansion strategy objectives. Thus, SAn telecom firms need to revisit their international HR strategy in order to boost chances of success in their operations beyond borders.

In addition, Hchaichi (2014:203) noted that a firm is "considered competitive if it can mobilise the most talented, best trained and most capable initiatives". Kerr \& Perdikis (2014:7) went on further to state that capital resources' access and its availability is important during expansion. Capital is a base, source and vehicle through which telecom firms expand. The 
entire spectrum of factor conditions revolves around resources. A firm's resources have a direct impact on the firm's competitiveness and on the deployment of strategies in emerging markets. Grant (2016:136) mentioned that what determines the resources' influence on firms' competitiveness is the "degree of efficiency and effectiveness in the way the resources are deployed in an industry".

SAn telecom firms are competitive compared to local market competitors. Their competitiveness is driven by sound telecom technology infrastructure which enhances quality service delivery. Thus, SAn telecom firms are doing well and managing industrial rivalry better in the market, for instance, Vodacom occupies $1^{\text {st }}$ and $2^{\text {nd }}$ position in all their markets of operation (Vodacom, 2015:15). The research highlighted that SAn firms are competitive in terms of service provision, product differentiation and network coverage. David \& David (2015:76) suggested that a firm's source of sustainable competitiveness is based on the resources a firm owns. SAn telecom firms have better infrastructure compared to competitors and this is a resource based view. Kabue \& Kilika (2016:98), stated that "resources are often more common than rare, more homogeneous than heterogeneous and more mobile than immobile". Hence, telecom firms have to bundle their resources in order to develop rare and difficult to imitate processes that act as a source of competitive advantages. Inimitability prompts long-term sustainable competitive advantages which enhances a firm's long-term performance.

Grant (2016:136) argued that as competition intensifies across the telecom industry, "very few business environments can guarantee secure returns". Hence, the primary goal of telecom firms' strategy should be to establish a position of competitive advantage for business sustainability and superior returns. This is supported by Barney (2001:45) who argued that a firm's source of competitive advantage is based on its entrepreneurial ability to create value better than competitors and this affirms the research's findings. SAn telecom firms have better products and services compared to competition. This will enable telecom firms to remain ahead of competition as long as the firms' capabilities are not replicated as suggested by Kabue \& Kilika (2016:99).

\subsubsection{Demand conditions}

The market's demand is determined by the presence of buyers. The more demanding and specific product and service choice the buyers are, the more differentiated the product and service requirement need there is. Most SAn telecom firms entered into emerging markets that showed potential for growth such as Nigeria and DRC. In the diamond model, 
competitiveness of a firm's products and services is only realised if there is a market for the products and services. It is imperative for telecom firms in SA to carefully assess the market's potential for their products, because absence of customers is detrimental to the firm's performance.

\subsubsection{Support industry, firm strategy and rivalry}

Competitive advantages are relative to a firm's entire economy; hence, it is vital for telecom companies to take cognisance of which countries to enter. Availability of supporting industries impacts a firm's value chain, and its competitiveness in the market. If suppliers to the telecom industry are internationally present in potential countries of operation, it acts as an advantage to telecom firms as they can easily source their equipment whilst reducing the average unit cost of operation (Stanlake, 2008:177). Industrial rivalry is high in the telecom industry because the market structure is highly concentrated. For SAn telecom firms to gain competitiveness, it is important that their strategy cements well-built-in capabilities which enable the firm's competitiveness and success. This position is determined by the firm's ownership structure, capital structure and the firm's management team.

\subsection{The five forces model in SAn telecom industry}

Porter's five forces model was used to analyse the telecom industry. These forces are governed by institutional frameworks, and mobile telecom firms in Africa are equally affected by these institutional frameworks. In any country, firms within the mobile industry exist in a realm of different factors which positively or negatively impact their business operations. The institutional frameworks and/or stakeholders include government, suppliers, buyers, competitors and labour groups, among others (Porter, 2001:1). The impact of these frameworks during telecom firms' expansion differs from one firm to another and from one country to another. Hence, it is important for SAn telecom firms to weigh the different levels of influence and impact, and strategize accordingly. These frameworks are discussed in line with Porter's five forces model shown in Figure 1. The five forces are the hard institutional aspects which shape and direct the firm's decisions; however, social, regulatory, and government are the soft aspects to the frame, which are important as they fuel business success or failure in Africa.

\subsubsection{Potential entrants}

The mobile telecom industry is highly regulated by governments through either independent or government-dependent telecom authorities. These authorities have an influence in the 
telecom operations and determine mobile operating license issues, among others. It is important for telecom firms in SA to embrace rules and regulations in their markets, as this has a direct influence in their foreign operations' success. In most emerging countries, the mobile telecom market structure is highly concentrated and the potential to enter these markets is low; hence, SAn firms have to be competitive enough to win any equity or potential license bid (Louw \& Venter, 2013:218). The low level of potential to entry is prompted by the regulatory and government authorities. In addition, the industry requires heavy capital investment which calls for adequate capital support from the parent investors (Deloitte, 2014:3). With advanced markets being saturated, they too are eyeing any equity or GSM license opportunity in Africa. Hence, it is important for SAn telecom firms to be highly competitive. Any opportunity to acquire equity stake or obtain an operating license assists SAn telecom firms' overall holding company's performance. Further, once in the market, adapting and complying with market requirements are fundamental cornerstones for success.

\subsubsection{Customers}

Profitability and company performance is a function of the availability of a market which is sufficient to generate profits for telecom firms. The mobile telecom industry is capital intensive; hence, ROI is an important informant factor that assists telecom firms in deciding which markets to enter (Gant, 2016:440). Further, an assessment of the level of risk in the market is essential. In emerging markets, customer behaviour varies from one market to another and telecom firms have to take this into consideration (Kotler \& Keller, 2016:179). Customer switching costs are low; therefore, a strong brand marketing thrust is essential to create brand loyalty. In addition, big data management tools can assist telecom firms to understand the market's behaviour in line with their product and service offering (Kotler \& Keller, 2016:179).

Customers' disposable income which is economy dependent determines the success of the firm's target market. In addition, the economy's performance determines the income level and spending habits of customers (Schiller, Hill \& Wall, 2013:183). It is important to analyse this multiplier effect in the decision-making process in any emerging market of operation (Stanlake, 2008:53). SAn telecom firms can only make more informed and accurate decisions during expansion by putting the customer in the economy's context and central to the firm's strategy processes. 
Figure 1: Porter's five forces model

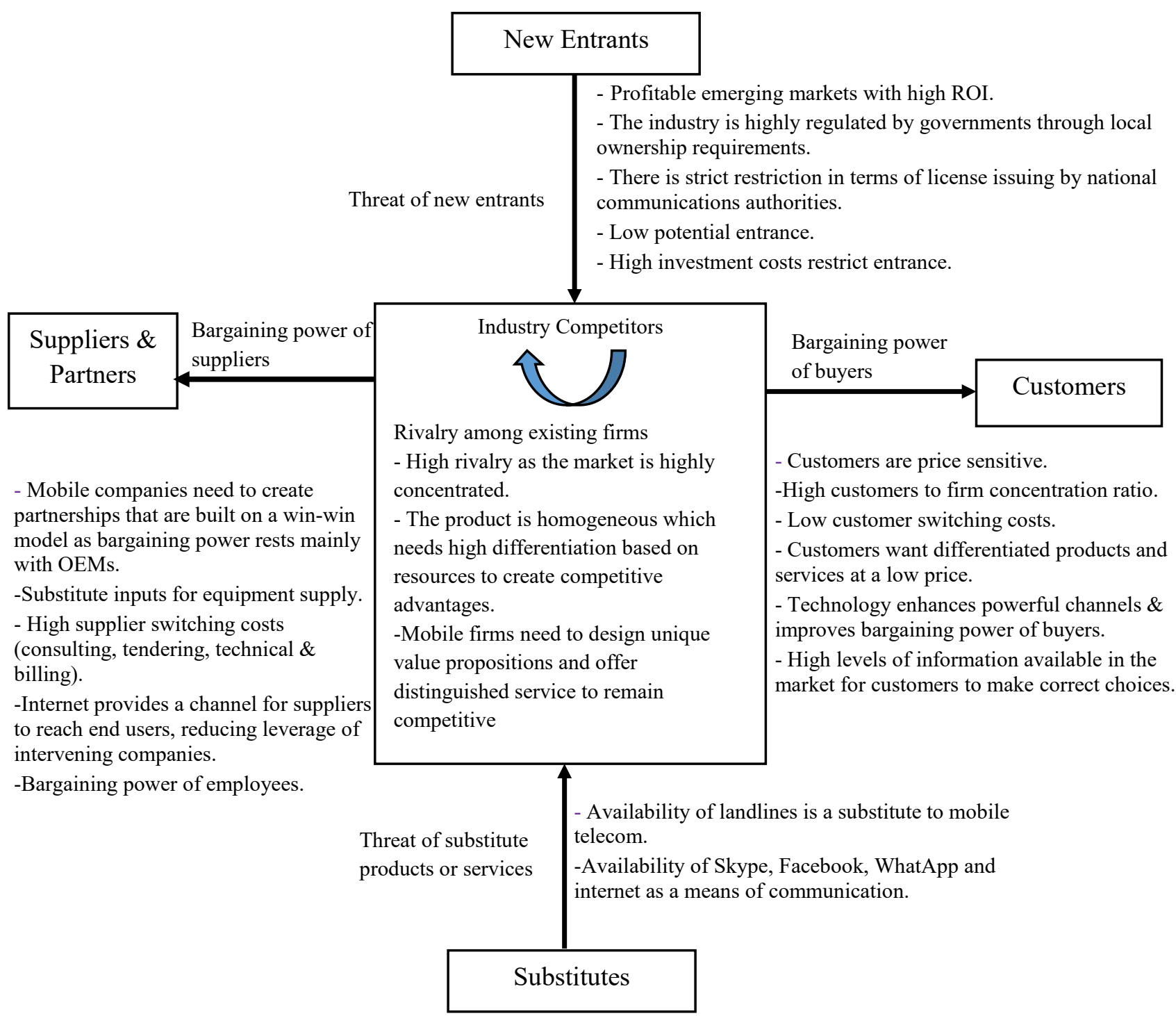

Source: Adapter from Thompson et al. (2016:57).

There is high availability of information in the market and customers are now more informed and exposed. For telecom firms to survive, use of smart big data is more essential than ever (Ernest \& Young, 2014:1). Further, selective location based marketing initiatives and strategies which are more specific and targeted are now imperative. Service and product differentiation stands as important for SAn telecom firms' competitiveness. This calls for a move from infrastructure based competition towards a service based business model.

\subsubsection{Suppliers}

This includes supply of labour skills, technology and equipment, among others. A good supply base has a direct impact on the supply chain end output product's quality and cost (Heizer \& Render, 2014:223). Local availability of suppliers is important as it assists in 
reducing operating costs. In addition, it reduces pressure from locally affiliated pressure groups that push for local procurement and employment of locals for domestic economic growth purposes. However, it has to be noted that telecom technology is mostly imported (Telkom, 2015:24). SAn telecom firms need to closely deliberate on importation of technology as it impacts various institutions of operation. The institutions include government (through import and income tax), local suppliers, labour unions (through the employment of locals) and the telecom firms' wish to transfer capabilities from the parent corporate, among others. All these aspects need to be weighed accordingly. According to Telkom, the supply chain side of their business contributes more towards the bulky cost structure of their operations (Telkom, 2015:24). To enhance cost efficiencies, SAn telecom firms have to closely evaluate their value chain systems.

\subsubsection{Substitutes}

Mobile telecom firms need to consider mobile telecom substitute product firms during expansion. It is critical to examine if there are regulatory institutions which control substitute product's impact and potential for entrance in the market. Too many substitutes can dilute profitability across the industry against high investment risk associated with the mobile telecom industry (Thompson et al., 2016:71). Substitute products (fixed telephones) directly impact the mobile telecom firm's potential for success in the market and its competitiveness. The availability of substitutes influences a firm's business strategy. Further, communication is now enabled through internet, Skype and WhatsApp, among other social modes of communication and this affects telecom firms' profitability. All these factors need to be considered.

\subsubsection{Industry rivalry}

It is important for SAn mobile telecom firms to review the intensity of industry rivalry and the regulating forces which are in place and ensure that the landscape is conducive for the firms' competitiveness. This assists SAn telecom firms to build sufficient capability muscle to compete in the industry. Industry rivalry must be carefully observed as there is potential for formation of cartels between telecom firms. There are allegations of cartels levelled against Net-One and Telecel in Zimbabwe (Chipunza, 2018:1). This industrial reality needs careful checks at all times. Further, other emerging market competition regulators are now easily approving mergers and acquisitions of firms. This impacts telecom firms' expansion as there is high risk and high potential of industrial rivalry and this needs close evaluation before any expansion decision is made. 


\subsection{Role of government in the telecom industry}

It is imperative and acceptable within emerging markets to have government influence because government is a major player in capital and infrastructural development in emerging markets. In addition, some African governments have equity stake in telecom firms; hence, they are important stakeholders in the industry (Chipunza, 2018:1).

The research observed that government interference into telecom industry's emerging markets is moving towards minimal levels. This augments the view that African markets operate in a mixed economy, which is probably moving towards a free market economy in the future. Pockets of government influence in the telecom industry are felt in the control of market entry into the industry. Emerging market governments influence market entry of telecom firms through the constitution or communication regulatory authority statutes. This happens particularly if the constitution or communication regulatory authority states that a certain number of firms have to participate in the mobile telecom industry. Schiller et al. (2013:137) postulated that if the market (e.g. telecom) is concentrated, profits are preserved for few market players. Hence, government's influence on telecom authorities in emerging markets does influence industrial rivalry in the telecom industry and that determines how profits are shared within that market.

In some instances, the regulatory control by African governments is in line with targets to reverse colonial era imbalances of the past. For instance, BEEE Act in SA. In Tanzania, Vodacom was negatively affected by government's directive aimed at empowering the locals. Vodacom was compelled to issue some shares to locals in Tanzania, and this impacted Vodacom's equity strategy and shareholding control. This is one of the challenges which SAn telecom companies face in emerging markets.

Non-compliance with government regulations has a detrimental effect on telecom firms. For instance, the MTN SIM card registration in Nigeria resulted in MTN being slapped with a fine (Ambekar, 2016:7). To curb such from occurring, Vodacom is currently enhancing its operations by putting in place a paperless registration of SIM cards in Tanzania and Mozambique in compliance with government directives on SIM registration (Vodacom, 2016:2). Further, the study highlighted that there is a constant need for telecom firms in emerging markets to constantly engage with the respective governments to reduce the negative impact or dissuade governments from making decisions that badly impacts the industry. 


\subsection{Compatibility of language and culture}

Language and culture is among the soft aspects that positively enable a firm's strategic expansion success into foreign markets. Traditionally, for communication and interaction purposes, firms are expanding into markets that resemble their tradition, cultural, language and values (Hill, 2012:86). This assists in ensuring that telecom firms avoid "institutional voids and the impact of regionalism and incremental agency costs" (Sigauke, 2014:47). It was observed that SA's culture is compatible with other emerging markets, and that is good for telecom firms.

Research found that as companies expand, there is a high likelihood that they expand in markets with similar language as their home country. Orange for instance, expanded into markets which are predominantly French speaking. In contrast, Vodacom expanded into Mozambique and DRC which are non-English speaking markets (Vodacom, 2017:1). Probably, based on the multi-language, massive market and factor mobility of labour in the telecom industry, SAn telecom firms are able to attract the right skills with good language proficiency in such markets (Stanlake, 2008:59).

\subsection{Africa's infrastructural challenges}

In this research, the infrastructural challenges that were highlighted include availability of proper functional roads, technology and electricity. The study observed that technology is one of the key movers in the telecom industry, and good investment in technology is good for telecom businesses during expansion into foreign markets. This research posited that African telecom firms are increasing capital expenditure investment in technology to enhance their operational efficiencies and increase network coverage. Thus, innovation in technology enhances operational efficiency, and it is an important competitive factor to consider as telecom firms expand into emerging markets.

Prior research by Cuervo-Cazurra \& Genc (2008:698) indicated that developed countries have competitive advantages in technology development. Hence, SAn telecom firms must differentiate their products technologically, if they are to be successful in their expansion endeavours. A close look at Telkom indicated that their operations were inefficient from a technological angle, among others. That negatively impacted their profitability and survival in the Nigerian market. Hashai \& Buckley (2014:1) suggested that firms are as good as their home background and this holds true to some extent. Advanced market telecom firms have a strong technology base as compared to emerging market telecom firms, and this to a lesser 
extent makes the competitive landscape uneven for emerging market telecom firms. Since Africa is growing towards industrialisation, it is imperative that African telecom (Original Equipment Manufacturers (OEMs)) companies improve their technology innovations and grow home based telecom solutions to enhance the competitiveness of African telecom firms in emerging markets.

The study showed that road as a means of transport is among the top highest infrastructural challenge in emerging markets. In Africa, more than $50 \%$ of the population stays in remote areas which are difficult to access by roads. Although communication is difficult in the remote areas, the rural market's potential is high compared to the urban market (Dhliwayo, 2013:1). Road is a primary means of transport during network expansion in remote areas; hence, insufficient road structures inhibit telecom firms' expansion into emerging markets, because firms consider ease of conducting business in a country as important. In addition, the study revealed that, electricity access is another inhibiting factor to successful expansion of SAn telecom companies, and this calls for more government investment into electricity infrastructure to support telecom growth and investment.

\subsection{Factors propelling international growth}

\subsubsection{Strategy}

The study posits that to a larger extent, strategy is a propeller for expansion in SAn mobile telecom industry. For instance, Vodacom's corporate strategy statement shows that international expansion is one of its fundamental strategic pillars (Vodacom, 2017:1). From an expansion perspective, most telecom firms highlighted that they are open to explore business growth opportunities beyond their borders, and this is strategic in perspective. The study observed that SAn telecom firms are mostly considering consolidation investment options as vehicles to expand. This is because investors are now more concerned with a quick ROI as compared to greenfield investments that take longer to recoup the initial outlay.

\subsubsection{Profitability}

The research revealed that profitability is a high propeller for expansion into emerging markets. This asserts Friedman's (1970:6) accession that being profitable is the only corporate social responsibility of a business. 


\subsubsection{Growth opportunities}

In addition to strategy and profitability, growth opportunities came in as an expansion propeller for SAn telecom firms. Growth opportunities scored the highest compared to all the variables explored under international expansion propellers. The study indicated that SAn mobile telecom firms' main reason for expanding into emerging markets was and is driven by the desire to grow the business. The research posits that African markets possess high potential for SAn telecom firms to achieve their business growth objectives. This is in line with the vast opportunities which emerging markets offer. Gerdeman (2012:2) posited that though there are growth opportunities in foreign markets, telecom firms have to consider the transferability and the competitiveness of their assets in these markets.

\subsubsection{Resources}

Resources were depicted as an enabler for telecom firms' expand. This demonstrates that SAn telecom companies do not expand because they have resources, but they expand because of their business strategic objectives and goals. The research had a low rating on resources as a propeller for expansion. Although it is difficult for a company to expand without resources, the availability of resources does not induce expansion of telecom firms into emerging markets, but they support the decision to expand. A good and sound resource structure, if efficiently utilised offers a high potential for success in foreign markets.

\subsubsection{Competitiveness}

Competitiveness was moderately rated in the study. This moderate score indicates that competitiveness is a means to an end. It is not the main expansion driver, it is an after effect that assists telecom firms to perform better and outwit competition in their firm's markets of existence. This affirms Barney \& Peteraf's (2003:309) assertion which emphasised that "transaction and capital costs are a necessity for the emergence of firms into foreign markets and not their competitiveness". This view is in contrast with MTN's expansion strategy out of SA. Although MTN's expansion could be interpreted as the firm's move in line with its business strategic objective, to a larger extent the expansion was due to MTN's failure to withstand Vodacom's competitiveness in the SAn market.

\subsubsection{Efficiency}

There was an emphatic low rating on efficiency as an expansion propeller in the study. This depicted that efficient operations do not stimulate expansion initiatives beyond borders. That is, efficiency is a means to an end which, if not properly executed, can result in closure of 
operations, for instance, Telkom closed Nigeria operations. Secondly, according to Ambekar (2016:8), MTN's string of misfortune in Nigeria had management inefficiency as one of the contributing factors. The new management team appointed in the late 2016 and early 2017 was mandated to unlock inefficiencies in the firm (Agency Staff, 2017:1). This demonstrates that though efficiencies might not be important in the initial expansion plans for mobile telecom firms, the post-firm's existence and performance is fundamentally affected by it, hence a proper value chain analysis is essential to eliminate bottlenecks in the system.

\section{CONCLUSION AND RESEARCH IMPLICATIONS}

There are growth opportunities in Africa for mobile telecom. The penetration rate of $38 \%$ shows that there is vast untapped potential in emerging markets (GSMA, 2014:2). In addition, the GDP growth rate in Africa is growing at a faster rate (5.5\%) second to China (Deloitte, 2014:4). This presents more growth opportunities for SAn telecom firms, as economic growth is supported by communication. Hence, the observed high score on 'expansion beyond borders priority' further underlines that firms' expansion beyond borders is important in SAn telecom firms.

Further, a study by Ernest \& Young (2009:5) and Deloitte (2014:3) showed that as a result of the growth in the telecom business, economic growth occurred. This illustrates that further expansion of telecom businesses in Africa has a multiplier effect on the economy, and SAn telecom firms have a potential opportunity to benefit in the process. However, tactical growth has to be observed because in some North African regions, the telecom industry is heading towards maturity with vast potential for growth still available in Sub-Sahara Africa (Deloitte, 2014:4).

By looking at the population distribution in Africa, majority of the people stay in rural areas, and this market is yet to be fully explored by telecoms. SAn firms have a chance to enjoy good revenue growth in these areas if they execute their network expansion investment strategy well. Given the growth potential in emerging markets, governments in Africa have a big role to play, which include uplifting their investment in infrastructure. The current infrastructure development is low and slow and the remote areas are the ones mostly affected. However, remote areas are the ones showing revenue potential for telecom firms. It is imperative for African governments to take a leading role in ensuring adequate infrastructure 
development, as there is much required particularly on roads, electricity and technology development as shown in the study (Qobo \& Dube, 2015:6).

The potential for growth in the telecom business in Africa presents itself with high competition. It is therefore important for SAn telecom firms to have competitive resources and efficient systems for operational purposes. Developed telecom firms are also tapping into emerging markets of Africa as their markets have reached maturity. This puts more pressure on industrial rivalry in the license and consolidation processes in African telecom markets. This means that telecom firms from SA need to step up their competitiveness in the markets. Further, literature indicated that developed market telecom firms have better technology, and resource power as compared to emerging market firms (Pant \& Ramachandra, 2012:237). It is recommended that SAn telecom firms stretch their resources muscle power and efficiency. This will enhance their competitiveness and success in their international strategy initiatives.

Africa is an interesting continent with diversity in languages, cultures, beliefs and values. South Africa being part of the African continent has her own values which are ingrained in the Ubuntu culture. The research results showed that SA's cultural diversity enables her to seamlessly engage with other African markets. The study observed that SA's language capability enables her to fit seamlessly in African markets. The compatibility of these two variables fuels the probability of success for SAn telecom companies in emerging markets. However, statistics from UNESCO (2015:) indicated that majority of African countries' language literacy rate is below the world's average of $86 \%$, and this stands as a threat for SAn telecom companies when doing business in Africa. Communication and engagement of local labour force is and will remain a challenge. Hence, there is need for African governments to take the initiative and improve education levels in their states for the better of Africa's development.

The study also highlighted that any future expansion by SAn telecom firms is likely to be in an English speaking country as communication is important in businesses. Hence, it is important for SAn telecom firms to do business in countries that have similar language, culture and values with SA. Further, the international mobility nature of the global labour force is also enabling ease transfer of skills from one country to another. However, stringent country laws regarding immigration have to be noted.

It was observed that SAn telecom firms have and will continue to expand in emerging markets as long as there are growth opportunities. The growth opportunities are well complemented by telecom companies' strategy which focuses on international growth. Thus, growth 
opportunities, firms' strategy and profitability were found to be the main strategic drivers for growth in SAn telecom firms. Other variables: competitiveness, resources and efficiency support international expansion of telecom companies, but they are not the main drivers of international growth. Their absence does not deter international expansion, but their presence coupled with good representation enhances successful implementation of international expansion strategies. This is in line with Herzberg's hygienic factors of motivation (Hersey, Blanchard \& Johnson, 2008:106).

In terms of HR management strategy, the study showed that SAn telecom firms are lagging on employee retention in emerging markets. One of the underpinning factors which spare international firms to success is their human resources. Human resources are fundamental in the implementation of the company's strategy in new grounds. This is achieved through maintenance of a pool of well dedicated international human resources that are committed to imparting the company's DNA to new employees. Such an HR thrust, if adopted by SAn telecom firms could enhance their chances of success in these international markets. Human capital management is important as SAn telecom firms expand. This is because human resources are the cornerstone in the actual strategy implementation process in foreign markets. Further, the competitiveness of SAn telecom firms' human resources strategy was low. This illustrates that a sound competitive HR strategy has to be formulated or revised, and should be continuously revisited as SAn telecom firms expand beyond borders.

The study found that resources are a fundamental propeller and not the main driver to investment in emerging markets. MTN expanded more into emerging markets as compared to Vodacom. Vodacom had more stable resources compared to MTN. It can be argued that availability of resources do not propel expansion, but they only facilitate expansion. Their presence does not induce international expansion of telecom firms, but the resources' absence restrains international expansion of telecom firms.

The research showed that technology competitiveness of telecom firms has greater impact on their performance during expansion beyond borders. Technology is one of the factors which form a base for capabilities development especially in technology industries like telecom. It was observed that the technology competitiveness of SAn telecom firms is lowly rated compared to advanced market firms. This position is a threat to SAn telecom firms' competitive position in emerging markets.

Though SAn firms showed that they lagged behind in terms of technology competitiveness, they are better rated in terms of market competitiveness as compared to developed market 
telecom firms. Though a firm might be strong on technology, it is important to ensure that adequate market analysis and strategy formulation is sound and relevant to different markets of operation. Further, research pointed out that firms that expand into markets similar to their home market stand a better chance of success as compared to companies that expand into markets different from their market of origin (Cuervo-Cazurra \& Genc, 2008:698). Most countries into which SAn telecom firms expanded are similar to SA, with only a few that are different. This enables SAn telecom firms' success.

Doing business in Africa is governed by certain institutions, factors and frameworks. The institutions, factors and frameworks impact telecom firms' success in one way or another. Government in Africa is still one of the main stakeholders which influence businesses in the continent. Further, government in most emerging markets is the biggest spender in the economy. The government might not have a direct say in the operations of an industry, but they do have great influence through shareholding, board of director seats, laws and regulations and economic controls, among others. For instance, in SA, the government has shareholding in Telkom.

Governments in Africa deregulated the telecom industry. However, the government has control in the telecom industry through different arms. These arms, to some extent influence, control and regulate the communication industry in most African countries. The different telecom boards, associations and organisations enabled the telecom deregulation process in Africa. However, it can be argued that government still has influence in the industry. For instance, Econet license issuing in Zimbabwe, Econet's oust in Nigeria, MTN license fine in Nigeria, MTN profit repatriation in Nigeria, Vodacom equity issue in Tanzania, among others indicates that governments still have control in telecom businesses. Proper and careful evaluation of the government's involvement is important as telecom firms expand.

An assessment of the economic problems in Africa indicated that infrastructural development is a threat to SAn telecom firms as they expand into emerging markets. Infrastructure development is the mandate of government, and SAn telecom firms have to assess government's commitment to infrastructure development when assessing future potential markets of entry in emerging markets as this has a bearing on their cost structure, ease of doing business and overall success in these markets. 


\section{RECOMMENDATIONS}

- It is recommended that SAn telecom firms engage with local governments when expanding into emerging markets to ensure ease of doing business.

- It is recommended that SAn telecom firms must focus on strategy, growth opportunities and profitability as key drivers to business growth. Resource strength, efficiencies and competitiveness must be taken as support variables to the business.

- $\quad$ SAn telecom firms are recommended to expand into markets with similar settings as SA.

\section{AREAS OF FURTHER STUDY}

A comparative study which explores institutional factors' influence in mobile telecom in emerging and developed markets is essential.

\section{REFERENCES}

[1] AGENCY STAFF. 2017. Shuter shakes up MTN management team. South Africa: Techcentral.[Internet:https://techcentral.co.za/shuter-shakes-up-mtn-management-team/73633/; downloaded on 2017-05-6].

[2] AMBEKAR P. 2016. MTN - Darkest before the dawn, Corospondent. The Coronation Fund Managers, Institutional Quarterly.

[3] BARNEY J. 2001. Is the resource based view a useful perspective for strategic management research? Yes. The Academic Management Review 26 (1):41-56.

[4] BARNEY JB \& PETERAF M. 2003. Unravelling the resources-based tangle. Management and Decision Economics 24:309 - 23.

[5] CASCIO WF. 2013. Managing human resources: Productivity, quality of work life, profits. $9^{\text {th }}$ ed. Boston, MA: McGraw-Hill Irwin.

[6] CHIPUNZA C. 2018. Former Net-One CEO, POTRAZ, Chairman cartels. [Internet: http://www.financialgazette.co.zw/heres-full-letter-submitted-to-mnangagwa-byformer-netone-ceo-supa-potraz-chairman-and-others-said-to-be-a-mafia-typecartel/; downloaded on 2018-01-07]. 
[7] CUERVO A \& GENC M. 2008. Transforming disadvantages into advantages: developing-country MNE in the least developed countries. Journal of International Business Studies 39 (6):957-979.

[8] DAVID RF \& DAVID RF. 2015. Strategic management concepts and cases. $15^{\text {th }}$ ed. UK: Pearson.

[9] DELOITTE. 2014. The future of telecoms in Africa: The blue print for the brave.

[10] DHLIWAYO J. 2013. A brief history of telecommunications in Africa. ICT Africa. [Internet: http://www.ictafrica.info/FullNews.php?id=10568; downloaded on 2015-1007].

[11] ERNST \& YOUNG. 2009. Africa connected: A telecommunication growth story. EY's Global communication centre.

[12] ERNST \& YOUNG. 2014. Big data: Changing the way business compete and operate. [Internet:http://www.ey.com/Publication/vwLUAssets/EY -

Big data: changing the way businesses operate/\%24FILE/EY-Insights-on-GRCBig-data.pdf; downloaded on 2016-04-25].

[13] FRIEDMAN M. 1970. 'The social responsibility of business is to increase its profit', New York Times Magazine. 13 September 1970. [Internet: http://umich.edu/ thecore/doc/Friedman.pdf; downloaded on 2015-09-25].

[14] GERDERMAN D. 2012. Location, location, location: The strategy of place. Business research for business leaders, Harvard Business School.

[15] GHEMAWAT P. 2008. Managing differences: The central challenge of global strategy. Harvard Business Review 85 (3):1-9.

[16] GLOBAL SYSTEM FOR MOBILE ASSOCIATION. 2014. The mobile economy report.

[Internet: https://www.gsmaintelligence.com/research/?file=bb688b369d64cfd5b4e05a 1 ccfcbcb48 \&download; downloaded on 2015-10-05].

[17] GLOBAL SYSTEM FOR MOBILE ASSOCIATION. 2015. The mobile economy report.

[Internet: https://www.gsma.com/mobileeconomy/archive/GSMA_ME_SubSaharanAfrica_2015.pd f; downloaded on 2016-11-09].

[18] GLOBAL SYSTEM FOR MOBILE ASSOCIATION. 2016. The mobile economy report. [Internet: https://www.gsma.com/mobileeconomy/archive/GSMA_ME_2016.pdf; downloaded on 2017-06-19].

[19] GRANT RM. 2016. Contemporary strategy analysis. 19 $9^{\text {th }}$ ed. Chichester: John Wiley. 
[20] GUPTA AK \& GOVINDARAJAN V. 2000. Managing global expansion: A conceptual framework. Business Horizons Review, March - April 2000.

[21] HASHAI N \& BUCKLEY P. 2014. Is competitive advantage a necessary condition for the emergence of multinational enterprise? Global Strategy Journal 4 (1).

[22] HCHAICHI R. 2014. Empirical analysis of business and social science. International Journal of Business and Social Science 5:203-209.

[23] HEIZER J \& RENDER B. 2014. Operations management: Sustainability and supply chain management. $11^{\text {th }}$ ed. England: Pearson Education.

[24] HERSEY P, BLANCHARD K \& JOHNSON D. 2008. Management of organisational behaviour: Utilizing human resources. $9^{\text {th }}$ ed. New Jersey: Prentice Hall.

[25] HILL CWL. 2012. International business: Competing in the global market place. $9^{\text {th }}$ ed. McGraw-Hill.

[26] IBUKUNU Y. 2017. Nigerian MP absolves MTN of illegal repatriation. [Internet: https://www.businesslive.co.za/bd/companies/telecoms-and-technology/2017-11-09nigerian-mps-absolve-mtn-of-illegal-repatriation/; downloaded on 2017-10-25].

[27] KABUE LW \& KILIKA J. 2016. Firm resources, core competences and sustainable competitive advantage: An integrative theoretical framework. Journal of Management and Strategy 7 (1):98-108.

[28] KERR W \& PERDIKIS N. 2014. A guide to the global business environment. The economics of international commerce.

[29] KOTLER P \& KELLER KL. 2016. Marketing management. 15 $5^{\text {th }}$ ed. Essex: Pearson Education.

[30] LOUW L \& VENTER P. 2013. Strategic management: Developing sustainability in Southern Africa. $3^{\text {rd }}$ ed. Oxford University Press.

[31] MAKETA LT. 2009. MTN entry strategy in Nigeria. Cape Town: University of Cape Town (MBA thesis).

[32] MTN. 2016. Annual financial report. [Internet: https://www.mtn.com/MTN\%20Service\%20Detail\%20Annual\%20Reports1/booklet.pdf; downloaded on 2017-05-10].

[33] MTN. 2017. [Internet: http://www.mtn.com; downloaded on 17-08-17].

[34] NG'WANAKILALA F. 2017. Vodacom Tanzania extends deadline for stock market listing. [Internet: https://www.moneyweb.co.za/news/companies-and-deals/vodacomtanzania-extends-deadline-for-stock-market-listing/; downloaded on 2017-07-23]. 
[35] PANT A \& RAMACHANDRAN J. 2012. Legitimacy beyond borders: Indian software services firms in the United States. Global Strategy Journal 2 (3):224-243.

[36] PORTER ME. 1990. The Competitive advantage of nations. New York: The Free Press.

[37] PORTER ME. 2001. Strategy and internet. Harvard Business Review 79 (3):63-78.

[38] QOBO M \& DUBE M. 2015. South Africa's foreign economic strategies in a changing global system. Economic Diplomacy Programme, Policy insights 07.

[39] REED M. 2009. Confusion reigns over M\&A in Middle East and Africa. Intelligence centre blog. [Internet: http://www.intelligencecentre.net/2016/06/08could-nationalismthreaten-telecoms-globalization/; downloaded on 2016-06-08].

[40] SCHILLER BR, HILL CD \& WALL SL. 2013. The economy today. $13^{\text {th }}$ ed. Boston: McGraw-Hill .

[41] SIGAUKE J. 2014. The company secretary's role in corporate governance: Private and public owned South African companies. Pretoria: University of South Africa. (MBL thesis-unpublished).

[42] STANLAKE GF. 2008. Introductory economics. Longman.

[43] TELKOM. 2015. Annual financial report 2015. [Internet: www.telkom.co.za/ir/apps_static/ir/.../financial/.../Telkom\%20IR\%202015\%20Final.P; downloaded on 2017-07-23].

[44] THOMPSON AT, STRICKLAND AJ \& GAMBLE JE. 2016. Crafting and executing strategy. $20^{\text {th }}$ ed. McGraw Hill.

[45] UNESCO. 2015. UIS data centre. Institute for statistics. UNESCO.

[46] VODACOM. 2011. Annual financial report 2011. [Internet: http://www.vodacom.com/pdf/integrated-reports/annual-report-2011/ar-full.pdf; downloaded on 2015-09-21].

[47] VODACOM. 2015. Annual financial report 2015. [Internet: http://www.vodacom.com/pdf/integrated-reports/integrated-report-2015/annualfinancial-statements.pdf; downloaded on 2016-07-05].

[48] VODACOM. 2016. Annual financial report 2016. [Internet: http://www.vodacom.co.za/cs/groups/public/documents/document/integrated-report2016-lores.pdf; downloaded on 2017-05-31].

[49] VODACOM. 2017. [Internet: http://www.vodacom.com; downloaded on 2015 - 2017]. 